\title{
FOOD HABITS AND FOOD AWARENESS AMONG UNIVERSITY FEMALE STUDENTS: COMPARATIVE STUDY
}

\author{
$B y$ \\ Sahloul;O.T
}

Department of Home Economics,

Faculty of Specific Education,

Damietta University, Damietta, Egypt.

Research Gournal Specific Fducation

Faculty of Specific Fducation

gMansoura University

ISSUE NO. 47, JULY. 2017

مجلة بحوث التربية النوعية - جامعة المنصورة

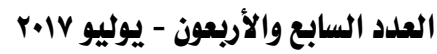




\title{
FOOD HABITS AND FOOD AWARENESS AMONG UNIVERSITY FEMALE STUDENTS: COMPARATIVE STUDY
}

\author{
Sahloul ; O. $T^{*}$
}

\section{Abstract}

This study was conducted to compare the food habits and food awareness among Damietta University female students, in the years 2007 and 2016. The researcher compared the results obtained in her Master's thesis in 2007 with the results obtained by the same questionnaire in 2016 . Education level, job level, food habits and food awareness was evaluated for 211 and 174 students, aged 18-23 years in the years 2007 and 2016 respectively. Obtained results showed that $41.2 \%, 33.3 \%$ of girls were good food awareness, $49.3 \%, 24.7 \%$ of girls were medium food awareness, 9.5\%, $41.9 \%$ of girls were poor food awareness in the years 2007 and 2016 respectively and the result difference is considered to be extremely statistically significant in Significant level 0.05 (t - 5.257, P value* 0.0001). This draws attention to the decline in food awareness among girls in 2016 than in 2007, Contrary to the researcher's expectation and may reflect the state of the decline of food culture in society experienced by the community in recent years in satellite channels and social media. In contrast, the ratio of $61 \%$, and $46.6 \%$ of girls eating sometimes between meals in the years 2007 and 2016 respectively. Relatively, time of eating between meals $36.5 \%, 31 \%$ of the girls was eating between breakfast and lunch, but $28 \%, 36.8 \%$ of the girls were eating a meal between lunch and dinner in the years 2007 and 2016 respectively. Finally, the most girls in both 2007 and 2016 prefer eating when they watching TV.

Key Words: food habits, food awareness, university female students, Questionnaires.

*Department of Home Economics, Faculty of Specific Education, Damietta University, Damietta, Egypt. 


\section{Introduction}

The transition from adolescence to adulthood is a critical stage in young people's life. Moreover, the interplay of social, psychological, and biological changes characteristic of this transitional period make them vulnerable to health problems and several risky behaviors, particularly unhealthy eating habits (Ganasegeran et al., 2012 and Aucott et al., 2014).

Changes are taking place in the food habits of the present-day Egyptians. Recent decades have witnessed the progressive erosion of the traditional Egyptian diet and insert new foods and eating habits (AbdelHady, and Ragaa; 2011).

(Mota et al., 2008) reported that main meals are often defined as eating breakfast, lunch and dinner. Researchers have regarded skipping breakfast as a behavior associated with the risk of becoming overweight during adolescence (Croezen et al., 2009 and Berkey et al., 2003).

(Najat et al., 2008) noted that Female students showed healthier eating habits compared to male students in terms of breakfast intake and meal frequency. $53.3 \%$ female students reported eating breakfast daily or three to four times per week compared to $52.1 \%$ male students.

(Abdallah et al., 2010) found that eating snacks was a common habit among students and its daily consumption was reported in $31.7 \%$ of them. With the exception of dates which are taken at least three times weekly by $60.5 \%$ of students, vegetables and fruits were not frequently consumed.

Relatively dietary behavior, they found that an association between the consumption of sugar-sweetened beverages and obesity (Keller; 2015).

(Vermeulen et al., 2017) found that no consistent evidence was found that consumption of a dietary pattern, high in nutrients that are hypothesized to protect against depression, was associated with lower depressive symptoms across different ethnic groups.

A recent study conducted among college students reported that increased knowledge of dietary guidance, Dietary Guidelines for Americans 
2005, appeared to be positively related to healthier eating patterns thus the better eaters had a higher level of knowledge about nutrition (Kolodinsky $\boldsymbol{e t}$ al., 2007).

This work aimed to: compare the food habits and food awareness among Damietta university female students in the years 2007 and 2016.

\section{Subjects and Methods}

A random sample of 211 and 174 university female students in the years 2007 and 2016 respectively, aged 18-23 years, were selected from Damietta University.

The study contains three questionnaires; as follows:

1) Indicate general data: name and age

2): Indicate educational family level and family occupation level

3): Recognize food habits.

4): Recognize food awareness. (Abd El-Salam, 1998 and Mehelba, 1999).

\section{Statistical analysis}

Data analysis was performed using spss.

$\mathrm{T}$ test was conducted to determine the existence of differences.

For all statistically significant at the $\mathrm{p}<0.05$ levels in bivariate analyses were included in the multivariable models. (Heba et al., 2016).

\section{Results and Discussion}

The data in table (1) and Figure (1) showed the comparison of female students by their family education level in 2007 and 2016. It is noted that $53(25.1 \%)$ in 2007 in compare with $44(25.3 \%)$ in 2016 of female students' father were high education level (university education), while 52 (24.6\%) in 2007 in compare with 45 (25.8\%) in 2016 of female students' father were middle education level (secondary education), also 23 (10.9\%) in 2007 in compare with 9 (5.2\%) in 2016 of female students' father were low education level (illiteracy education). This proved that the most of female students' father in 2007 were in high education level in compare 
with the same in 2016 the most of female students' father were middle education level.

Relationship between father education level in 2007 and 2016 indicated that the difference is considered to be not statistically significant in Significant level 0.05( $\mathrm{t}=1.362$, $\mathrm{P}$ value $=0.1785)$.

In this regard for female students' mother it is noted that 43 (20.4\%) in 2007 in compare with $39(22.4 \%)$ in 2016 were high education level (university education), while $60(28.4 \%)$ in 2007 in compare with 59 (33.9\%) in 2016 were middle education level (secondary education). This proved that the most of female students' mother in 2007 and 2016 were in middle education level.

Relationship between mother education level in 2007 and 2016 indicated that the difference is considered to be extremely statistically significant in Significant level $0.05(t=3.339$, P value $=0.0008)$.

In this respect, Abd El-Salam (1998) reported that maximal prevalence of Low Education level, Middle Education level, and High Education level in normal weight (\%40), (\%49.5) and (\%49.4) respectively.

Table (1): Frequency and distribution compare to students by their family education level in 2007 and 2016.

\begin{tabular}{|c|c|c|c|c|c|c|c|c|c|}
\hline \multirow{3}{*}{\multicolumn{2}{|c|}{ Educational family level }} & \multicolumn{4}{|c|}{ Father } & \multicolumn{4}{|c|}{ Mother } \\
\hline & & \multicolumn{2}{|c|}{2007} & \multicolumn{2}{|c|}{2016} & \multicolumn{2}{|c|}{2007} & \multicolumn{2}{|c|}{2016} \\
\hline & & No & $\%$ & No & $\%$ & No & $\%$ & No & $\%$ \\
\hline \multirow{3}{*}{$\begin{array}{c}\text { Low education } \\
\text { level }\end{array}$} & Illite & 23 & $10.9 \%$ & 9 & $5.2 \%$ & 34 & $16.1 \%$ & 10 & $5.75 \%$ \\
\hline & Read & 35 & $16.6 \%$ & 27 & $15.5 \%$ & 28 & $13.3 \%$ & 10 & $5.75 \%$ \\
\hline & mary & 30 & $14.2 \%$ & 21 & $12.1 \%$ & 27 & $12.8 \%$ & 21 & $12.1 \%$ \\
\hline \multirow{2}{*}{\begin{tabular}{|c|} 
Middle \\
education level
\end{tabular}} & Preparatory & 18 & $8.5 \%$ & 28 & $16.1 \%$ & 19 & $9 \%$ & 35 & $20.1 \%$ \\
\hline & Seconda & 52 & $24.6 \%$ & 45 & $25.8 \%$ & 60 & $28.4 \%$ & 59 & $33.9 \%$ \\
\hline $\begin{array}{c}\text { High education } \\
\text { level }\end{array}$ & Unive & 53 & $25.1 \%$ & 44 & $25.3 \%$ & 43 & $20.4 \%$ & 39 & $22.4 \%$ \\
\hline \multicolumn{2}{|c|}{ Total } & 211 & $100 \%$ & 174 & $100 \%$ & 211 & $100 \%$ & 174 & $100 \%$ \\
\hline
\end{tabular}




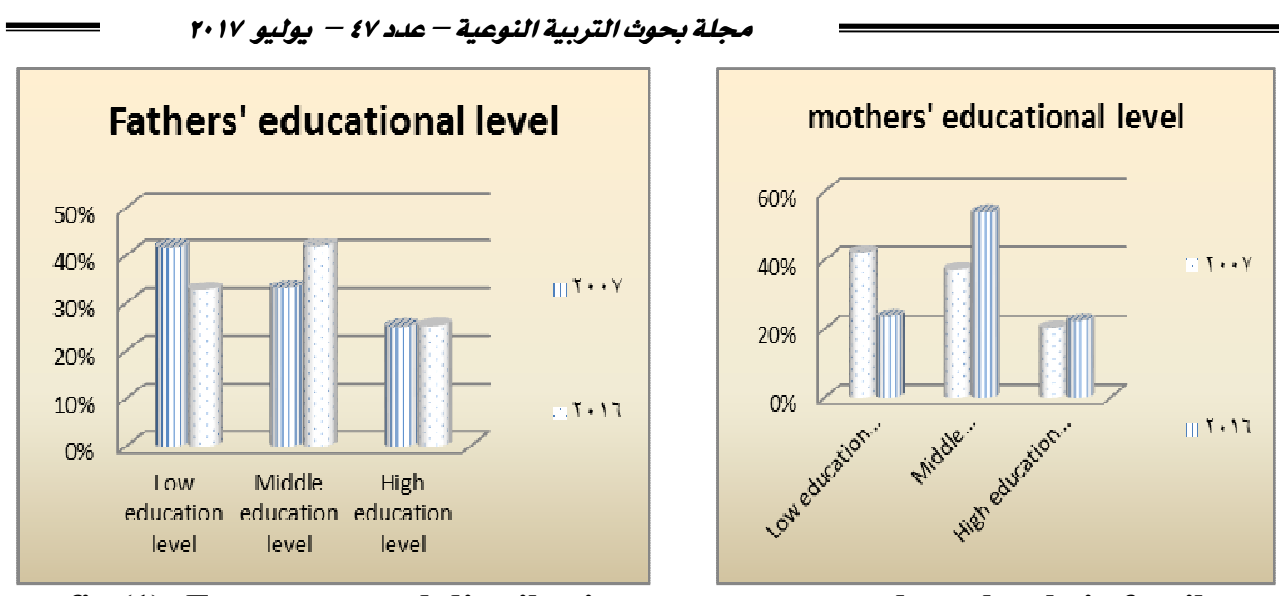

fig (1): Frequency and distribution compare to students by their family education level in 2007 and 2016.

$$
\begin{array}{ll}
\mathrm{t}=1.362 & \mathrm{P} \text { value }=0.1785 \text { (fathers) } \\
\mathrm{t}=3.3391 & \text { P value }=0.0008 \text { (mothers) }
\end{array}
$$

The results in table (2) and Figure (2) showed the comparison of female students by their family occupation level in 2007 and 2016. It is noted that 94 (44.5\%) in 2007 in compare with 86 (49.4\%) in 2016 of female students' father were workers, while $99(46.9 \%)$ in 2007 in comparing with76 (43.7\%) in 2016 of female students' father worked in (traditional- industrial- governmental). This proved that the most of female students' father in 2007 works in (traditional- industrial- governmental), while in 2016 the most of female students' father was a worker.

Relationship between father job level in 2007 and 2016 indicated that the difference is considered to be not statistically significant in Significant level 0.05( $\mathrm{t}=1.544$, $\mathrm{P}$ value $=0.1234)$.

Regarding female students' mother, It is noted that $142(67.3 \%)$ in 2007 in compare with 134(77\%) in 2016 didn't work, while $64(30.3 \%)$ in 2007 in compare with 32 (18.4\%) in 2016 worked in (traditional- industrialgovernmental). This proved that the most of female students' mother in 2007 and 2016 didn't work.

Relationship between mother job level in 2007 and 2016 indicated that the difference is considered to be extremely statistically significant in Significant level $0.05(\mathrm{t}=2.135$, $\mathrm{P}$ value $=0.0334)$. 
- Food Habits and Food Awareness Among University Female Students: Comparative Study

Table (2): Frequency and distribution compare to students by their family occupation level in 2007 and 2016.

\begin{tabular}{|c|c|c|c|c|c|c|c|c||}
\hline \multirow{2}{*}{ Family occupation level } & \multicolumn{4}{|c|}{ Father } & \multicolumn{4}{|c|}{ Mother } \\
\cline { 2 - 10 } & \multicolumn{2}{|c|}{2007} & \multicolumn{2}{|c|}{2016} & \multicolumn{2}{|c|}{2007} & 2016 \\
\cline { 2 - 10 } & No & $\%$ & No & $\%$ & No & $\%$ & No & $\%$ \\
\hline \hline Not work & 0 & $0 \%$ & 2 & $1.2 \%$ & 142 & $67.3 \%$ & 134 & $77 \%$ \\
\hline Workers & 94 & $44.5 \%$ & 86 & $49.4 \%$ & 0 & $0 \%$ & 3 & $1.7 \%$ \\
\hline $\begin{array}{c}\text { Another (traditional- } \\
\text { industrial- governmental })\end{array}$ & 99 & $46.9 \%$ & 76 & $43.7 \%$ & 64 & $30.3 \%$ & 32 & $18.4 \%$ \\
\hline Advanced & 18 & $8.5 \%$ & 10 & $5.7 \%$ & 5 & $2.4 \%$ & 5 & $2.9 \%$ \\
\hline \hline Total & 211 & $100 \%$ & 174 & $100 \%$ & 211 & $100 \%$ & 174 & $100 \%$ \\
\hline
\end{tabular}
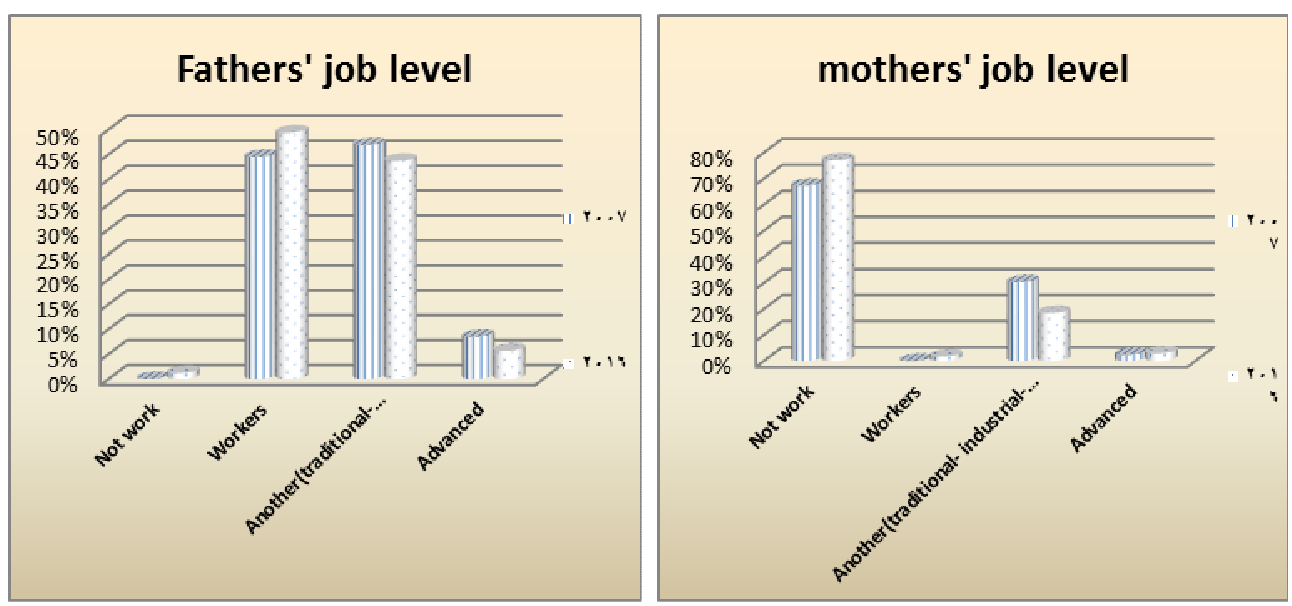

Figure (2): Frequency and distribution compare to students by their family occupation level in 2007 and 2016.

$$
\begin{array}{ll}
\mathrm{t}=1.544 & \mathrm{P} \text { value }=0.1234 \text { (fathers) } \\
\mathrm{t}=2.135 & \mathrm{P} \text { value }=0.0334 \text { (mothers) }
\end{array}
$$

Data in table (3) and Figure (3) showed the comparison of female students by their daily main meals they took in 2007 and 2016. It is noted that most of female student 78 (37\%), 85 (48.9\%) eats breakfast, lunch, and dinner daily in the years 2007 and 2016 respectively. 
Relationship between daily main meals in 2007 and 2016 indicated that the difference is considered to be not statistically significant in Significant level $0.05(\mathrm{t}=.455, \mathrm{P}$ value $=0.6494)$.

These findings aren't in agreement with Najat et al (2008) found that the majority of students (52.7\%) reported eating two meals per day.

Table (3): Distribution of students according to main meals taken per day in 2007 and 2016.

\begin{tabular}{|c|c|c|c|c|c|c|c|c|c|c|c|c|c|c|c|c|}
\hline \multirow{3}{*}{$\begin{array}{c}\text { Main } \\
\text { meals were } \\
\text { taken daily }\end{array}$} & \multicolumn{4}{|c|}{$\begin{array}{c}\text { Breakfast, } \\
\text { Lunch and Dinner }\end{array}$} & \multicolumn{4}{|c|}{ Lunch and Dinner } & \multicolumn{4}{|c|}{$\begin{array}{c}\text { Breakfast and } \\
\text { Lunch }\end{array}$} & \multicolumn{4}{|c|}{$\begin{array}{c}\text { Breakfast and } \\
\text { Dinner }\end{array}$} \\
\hline & \multicolumn{2}{|c|}{2007} & \multicolumn{2}{|c|}{2016} & \multicolumn{2}{|c|}{2007} & \multicolumn{2}{|c|}{2016} & \multicolumn{2}{|c|}{2007} & \multicolumn{2}{|c|}{2016} & \multicolumn{2}{|c|}{2007} & \multicolumn{2}{|c|}{2016} \\
\hline & $\mathrm{N}$ & $\%$ & $\mathrm{~N}$ & $\%$ & $\mathrm{~N}$ & $\%$ & $\mathrm{~N}$ & $\%$ & $\mathrm{~N}$ & $\%$ & $\mathrm{~N}$ & $\%$ & $\mathrm{~N}$ & $\%$ & $\mathrm{~N}$ & $\%$ \\
\hline Total & 78 & $37 \%$ & 85 & $48.9 \%$ & 72 & $34.1 \%$ & 26 & $14.9 \%$ & 57 & $27 \%$ & 59 & $33.9 \%$ & 4 & $1.9 \%$ & 4 & 2.3 \\
\hline
\end{tabular}

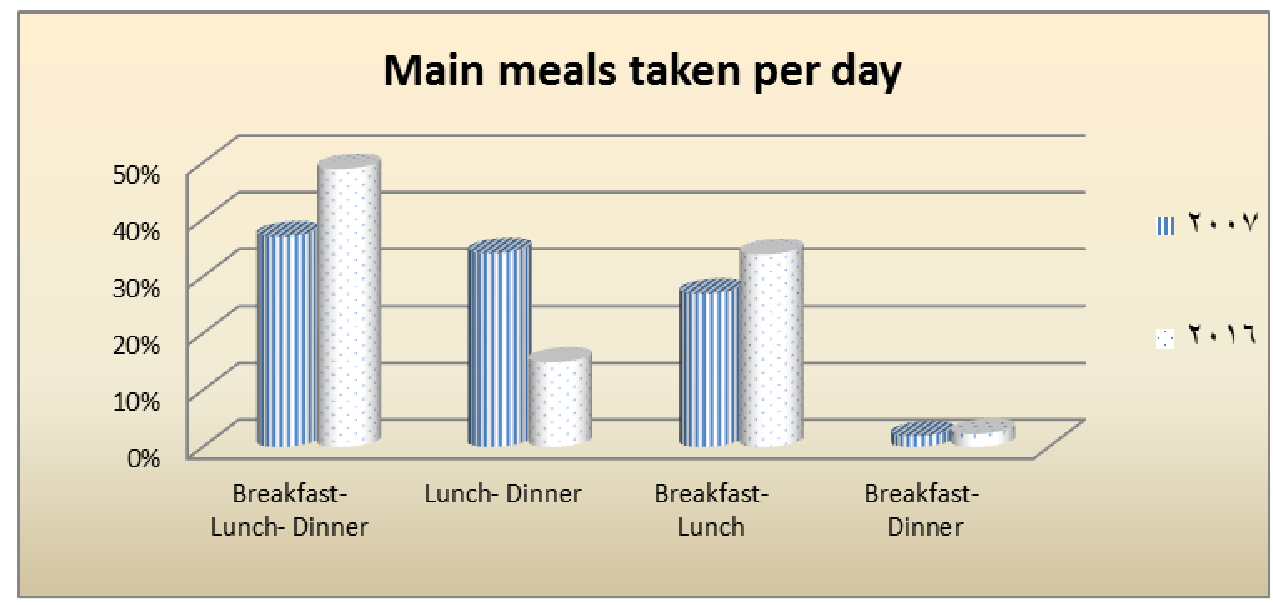

Figure (3): Distribution of students according to main meals taken per day in 2007 and 2016.

$$
\mathrm{t}=0.455 \quad \mathrm{P} \text { value }=0.6494
$$

The results in table (4) and Figure (4) showed the comparison of female students by their daily main meal they taken in 2007 and 2016. It is noted that most of female student 190 (90\%), 134 (77\%) eats lunch as a main meal daily in the years 2007 and 2016 respectively. 
Relationship between daily main meal in 2007 and 2016 indicated that the difference is considered to be not statistically significant in Significant level $0.05(\mathrm{t}=1.104$, $\mathrm{P}$ value $=0.2703)$.

On the other hand Abdallah et al (2010) concluded that although irregular meals consumption was reported in $63.3 \%$ of students, the vast majority of them $88.6 \%$ have breakfast at least three times per week.

Table (4): Distribution of students according to main meal taken per day in 2007 and 2016.

\begin{tabular}{|c|c|c|c|c|c|c|c|c|c|c|c|}
\hline \multirow{3}{*}{$\begin{array}{c}\text { Main meal } \\
\text { taken }\end{array}$} & \multicolumn{3}{|c|}{ Breakfast } & \multicolumn{4}{|c|}{ Lunch } & \multicolumn{4}{|c|}{ Dinner } \\
\hline & 2007 & \multicolumn{2}{|c|}{2016} & \multicolumn{2}{|c|}{2007} & \multicolumn{2}{|c|}{2016} & \multicolumn{2}{|c|}{2007} & \multicolumn{2}{|c|}{2016} \\
\hline & \begin{tabular}{|l|l}
$\mathrm{LN}$ & $\%$ \\
\end{tabular} & $\mathrm{~N}$ & $\%$ & $\mathrm{~N}$ & $\%$ & $\mathrm{~N}$ & $\%$ & IN & $\%$ & $\mathrm{~N}$ & $\%$ \\
\hline Total & \begin{tabular}{|l|l|}
18 & $8.5 \%$
\end{tabular} & 30 & $17.2 \%$ & 190 & $90 \%$ & 134 & $77 \%$ & 3 & $1.4 \%$ & 10 & $5.8 \%$ \\
\hline
\end{tabular}

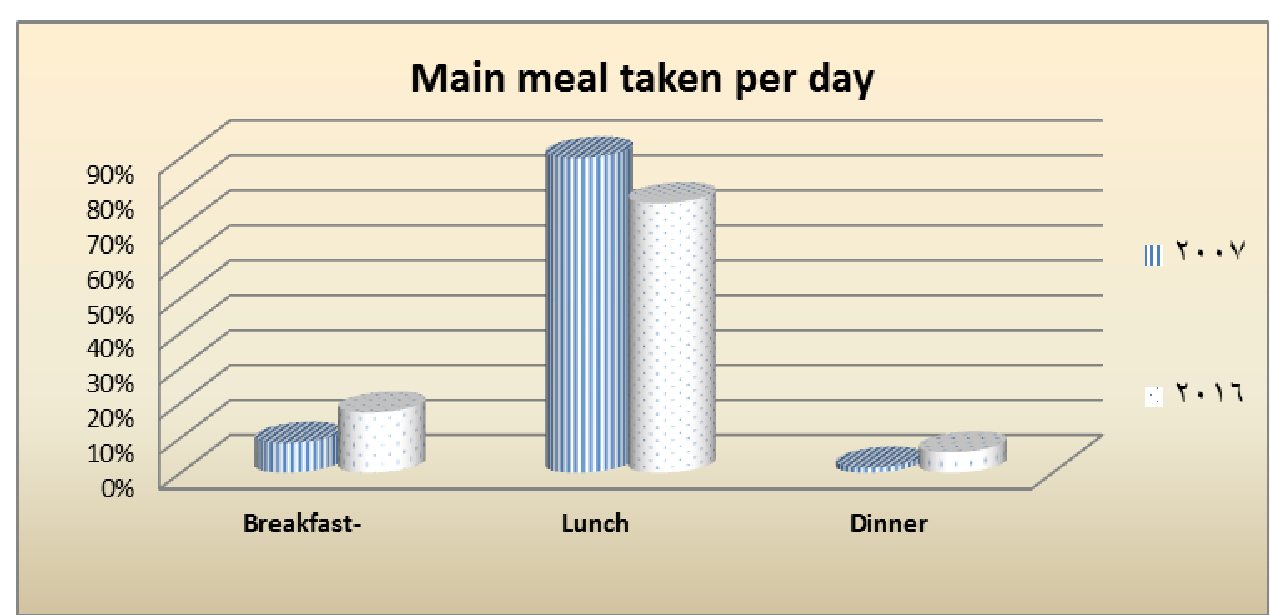

Figure (4): Distribution of students according to main meal taken per day in 2007 and 2016.
$\mathrm{t}=1.104$
$\mathrm{P}$ value $=0.2703$

The data in table (5) and Figure (5) showed the comparison of female students according to eating between meals in 2007 and 2016. It is noted that most of female student 129(61\%), 81 (46.6\%) sometimes eats between meals in the years 2007 and 2016 respectively. while $40(19 \%) 49$ 
مجلة بحوث التربية النوعية- عدد IV - يوليو

(28.2\%) not always eats between meals in the years 2007and 2016 respectively.

Relationship between eating between meals in 2007 and 2016 indicated that the difference is considered to be not statistically significant in Significant level $0.05(t=0.393$, $P$ value $=0.6945)$.

Table (5): Distribution of students by their eating between meals in 2007 and 2016.

\begin{tabular}{|c|c|c|c|c|c|c|c|c|c|c|c|c|c|c|c|c|}
\hline \multirow{3}{*}{$\begin{array}{c}\text { Eating } \\
\text { between } \\
\text { meals } \\
\end{array}$} & \multicolumn{4}{|c|}{ Yes } & \multicolumn{4}{|c|}{ Sometimes } & \multicolumn{4}{|c|}{ Not always } & \multicolumn{4}{|c|}{ No } \\
\hline & \multicolumn{2}{|c|}{2007} & \multicolumn{2}{|c|}{2016} & \multicolumn{2}{|c|}{2007} & \multicolumn{2}{|c|}{2016} & \multicolumn{2}{|c|}{2007} & \multicolumn{2}{|c|}{2016} & \multicolumn{2}{|c|}{2007} & \multicolumn{2}{|c|}{2016} \\
\hline & $\mathrm{N}$ & $\%$ & $\mathrm{~N}$ & $\%$ & $\mathrm{~N}$ & $\%$ & $\mathrm{~N}$ & $\%$ & $\mathrm{~N}$ & $\%$ & $\mathrm{~N}$ & $\%$ & $\mathrm{~N}$ & $\%$ & $\mathrm{~N}$ & $\%$ \\
\hline Total & 21 & $10 \%$ & 27 & $15.5 \%$ & 129 & $61 \%$ & 81 & $46.6 \%$ & 40 & $19 \%$ & 49 & $28.2 \%$ & 21 & $10 \%$ & 17 & $9.8 \%$ \\
\hline
\end{tabular}

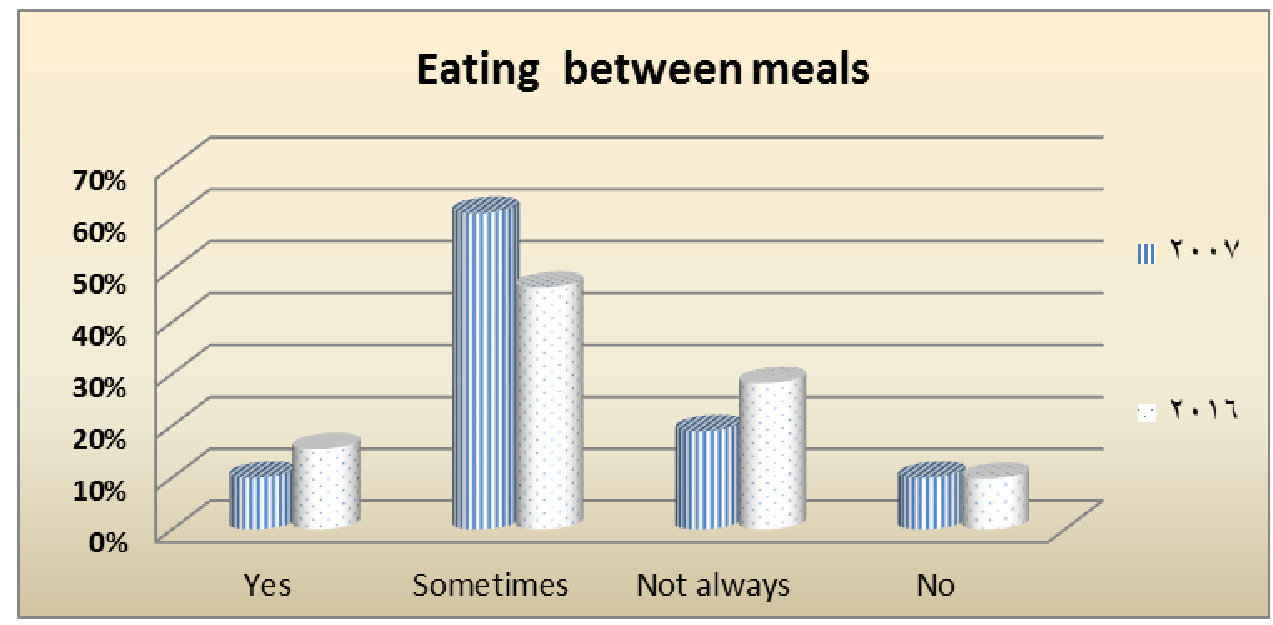

Figure (5): Distribution of students by their eating between meals in 2007 and 2016.

$$
\mathrm{t}=0.393 \quad \mathrm{P} \text { value }=0.6945
$$

The results in table (6) and Figure (6) showed the comparison of female students according to time of eat between meals in 2007 and 2016. It is noted that $77(36.5 \%)$ in 2007and $48(27.6 \%)$ in 2016 of female student eating between breakfast and lunch. while 59(28\%) in 2007and 64 (36.8\%) in 2016 of female student eating between lunch and dinner. 
Relationship between time of eat between meals in 2007 and 2016 indicated that the difference is considered to be not statistically significant in Significant level $0.05(\mathrm{t}=1.385$, P value $=0.1669)$.

Table (6): Distribution of students according to time of eats between meals in 2007 and 2016.

\begin{tabular}{|c|c|c|c|c|c|c|c|c|c|c|c|c|c|c|c|c|}
\hline \multirow{3}{*}{$\begin{array}{c}\text { Time of } \\
\text { eat } \\
\text { between } \\
\text { meals }\end{array}$} & \multicolumn{4}{|c|}{ Nothing } & \multicolumn{4}{|c|}{$\begin{array}{c}\text { Between } \\
\text { Breakfast\& } \\
\text { Lunch }\end{array}$} & \multicolumn{4}{|c|}{$\begin{array}{c}\text { Between Lunch\& } \\
\text { Dinner }\end{array}$} & \multicolumn{4}{|c|}{$\begin{array}{l}\text { After the } \\
\text { Dinner }\end{array}$} \\
\hline & \multicolumn{2}{|c|}{2007} & \multicolumn{2}{|c|}{2016} & \multicolumn{2}{|c|}{2007} & \multicolumn{2}{|c|}{2016} & \multicolumn{2}{|c|}{2007} & \multicolumn{2}{|c|}{2016} & \multicolumn{2}{|c|}{2007} & \multicolumn{2}{|c|}{2016} \\
\hline & $\mathrm{N}$ & $\%$ & $\mathrm{~N}$ & $\%$ & $\mathrm{~N}$ & $\%$ & $\mathrm{~N}$ & $\%$ & $\mathrm{~N}$ & $\%$ & $\mathrm{~N}$ & $\%$ & $\mathrm{~N}$ & $\%$ & $\mathrm{~N}$ & $\%$ \\
\hline Total & 68 & $32.2 \%$ & 54 & $31 \%$ & 77 & $36.5 \%$ & 48 & $27.6 \%$ & 59 & $28 \%$ & 64 & $36.8 \%$ & 7 & $3.3 \%$ & 8 & $4.6 \%$ \\
\hline
\end{tabular}

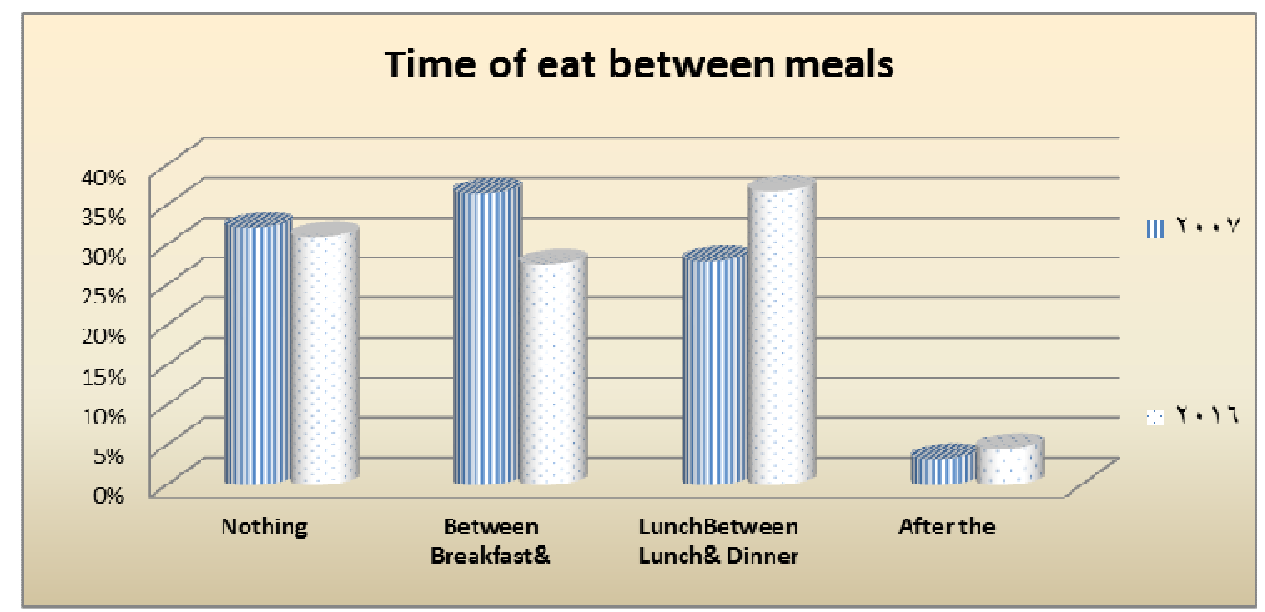

Figure (6): Distribution of students according to time of eats between meals in 2007 and 2016.

$$
\mathrm{t}=1.385 \quad \mathrm{P} \text { value }=0.1669
$$

The results in table (7) and Figure (7) showed the comparison of female students according to eating out of home in 2007 and 2016. It is noted that $163(77.3 \%) 115(66.1 \%)$, of female student eating sometimes out of home in the years 2007 and 2016 respectively. But 29(13.7\%), 39 (22.4\%) eating all the time out of home in the years 2007 and 2016 respectively. 
Relationship between time of eating out of home in 2007 and 2016 indicated that the difference is considered to be not statistically significant in Significant level $0.05(\mathrm{t}=1.156, \mathrm{P}$ value $=0.2484)$.

In this respect Najat et al (2008) reported that the unhealthy eating practice was indicated by the fact that the majority (57.3\%) of the students reported eating fried food more than three times per week. Among females, $54 \%$ reported eating fried food daily or three to four times per week compared to $61.4 \%$ males. Daily intake of snacks apart from regular meals was more common among females than males $(55.6 \%$ vs. $50 \%$ respectively).

Table (7): Distribution of students according to eating out of home in 2007 and 2016.

\begin{tabular}{|c|c|c|c|c|c|c|c|c|c|c|c|c|}
\hline \multirow{3}{*}{$\begin{array}{l}\text { Eating } \\
\text { out of } \\
\text { home } \\
\end{array}$} & \multicolumn{4}{|c|}{ All the time } & \multicolumn{4}{|c|}{ Sometimes } & \multicolumn{4}{|c|}{ No } \\
\hline & \multicolumn{2}{|c|}{2007} & \multicolumn{2}{|c|}{2016} & \multicolumn{2}{|c|}{2007} & \multicolumn{2}{|c|}{2016} & \multicolumn{2}{|c|}{2007} & \multicolumn{2}{|c|}{2016} \\
\hline & $\mathrm{N}$ & $\%$ & $\mathrm{~N}$ & $\%$ & $\mathrm{~N}$ & $\%$ & $\mathrm{~N}$ & $\%$ & $\mathrm{~N}$ & $\%$ & $\mathrm{~N}$ & $\%$ \\
\hline Total & 29 & $13.7 \%$ & 39 & $22.4 \%$ & 163 & $77.3 \%$ & 115 & $66.1 \%$ & 19 & $9 \%$ & 20 & $11.5 \%$ \\
\hline
\end{tabular}

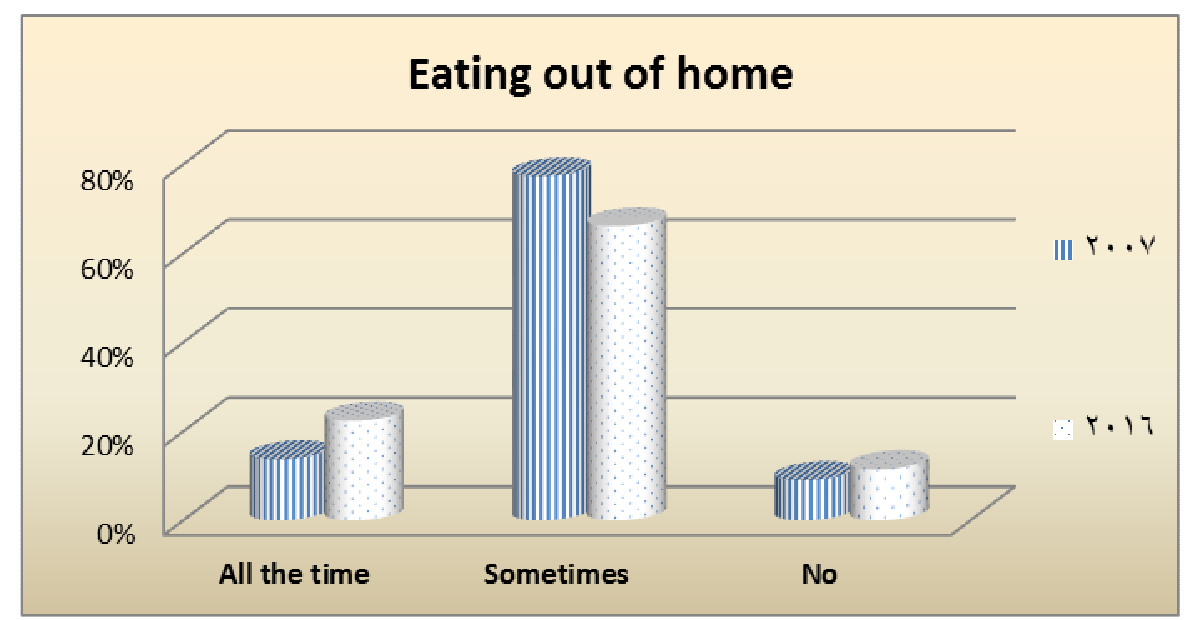

Figure (7): Distribution of students according to eating out of home in 2007 and 2016.
$\mathrm{t}=1.156$
$P$ value $=0.2484$ 
The data in table (8) and Figure (8) showed the comparison of female students according to making other things during eating in years 2007 and 2016. It is noted that 133(63\%), 76 (43.7\%) of female student making other things sometimes during eating in the years 2007and 2016 respectively. while $57(27 \%), 83(47.7 \%)$ don't make other any things during eating in the years 2007 and 2016 respectively.

Relationship between making other things during eating in 2007 and 2016 indicated that the difference is considered to be extremely statistically significant in Significant level $0.05(\mathrm{t}=3.484$, P value $=0.0006)$.

Table (8): Distribution of students according to making other things during eating in years 2007 and 2016.

\begin{tabular}{|c|c|c|c|c|c|c|c|c|c|c|c|c|}
\hline \multirow{3}{*}{$\begin{array}{c}\text { Making } \\
\text { another thing } \\
\text { during eating. } \\
\end{array}$} & \multicolumn{4}{|c|}{ All the time } & \multicolumn{4}{|c|}{ Sometimes } & \multicolumn{4}{|c|}{ No } \\
\hline & \multicolumn{2}{|c|}{2007} & \multicolumn{2}{|c|}{2016} & \multicolumn{2}{|c|}{2007} & \multicolumn{2}{|c|}{2016} & \multicolumn{2}{|c|}{2007} & \multicolumn{2}{|c|}{2016} \\
\hline & $\mathrm{N}$ & $\%$ & $\mathrm{~N}$ & $\%$ & $\mathrm{~N}$ & $\%$ & $\mathrm{~N}$ & $\%$ & $\mathrm{~N}$ & $\%$ & $\mathrm{~N}$ & $\%$ \\
\hline Total & 21 & $10 \%$ & 15 & $8.6 \%$ & 133 & $63 \%$ & 76 & $43.7 \%$ & 57 & $27 \%$ & 83 & $47.7 \%$ \\
\hline
\end{tabular}

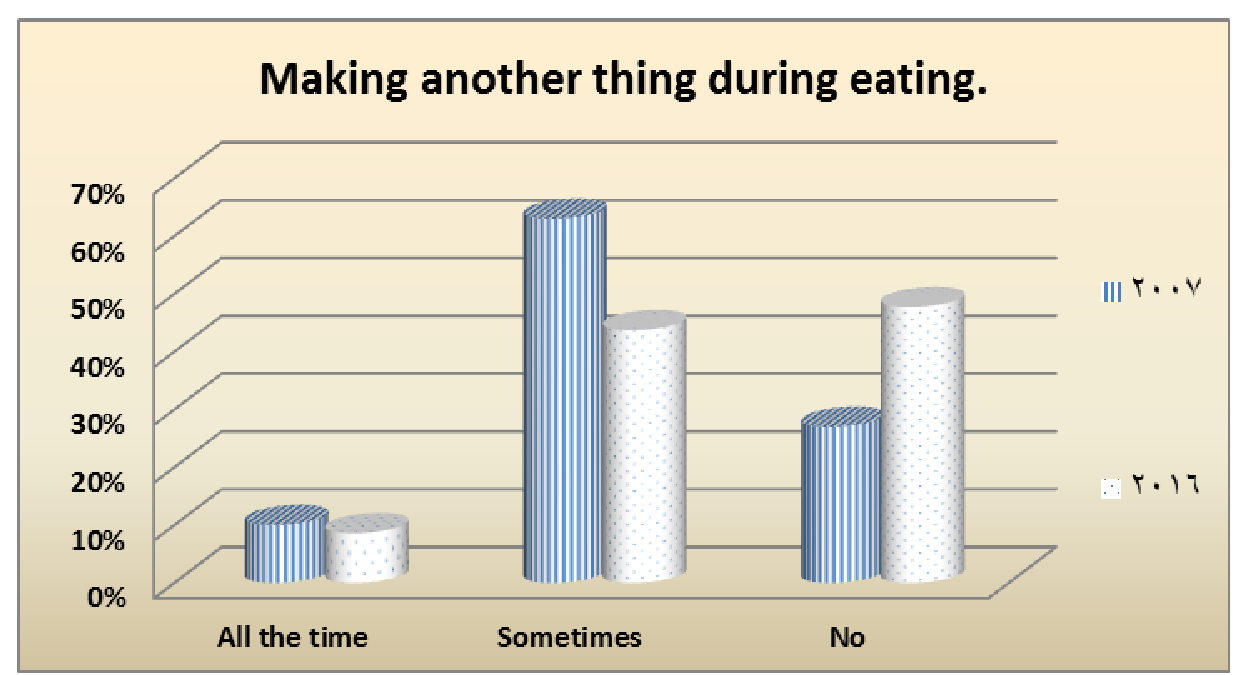

Figure (8): Distribution of students according to making other works during eating in 2007 and 2016.

$$
\mathrm{t}=3.484 \quad \mathrm{P} \text { value }=0.0006
$$


The data in table (9) and Figure (9) showed the comparison of female students according to eating when they are tension or boring in years 2007 and 2016. It is noted that the most of female student 110(52.1\%), 71 $(40.8 \%)$ don't eat anything when they are tension or boring in the years 2007 and 2016 respectively. While 82(38.9\%), 60 (34.5\%) eat sometimes when they are tension or boring in the years 2007 and 2016 respectively.

Relationship between eating when they are tension or boring in 2007 and 2016 indicated that the difference is considered to be extremely statistically significant in Significant level $0.05(t=2.758, P$ value $=0.0006)$.

Table (9): Distribution of students according to eating because of tension or boring in 2007 and 2016.

\begin{tabular}{|c|c|c|c|c|c|c|c|c|c|c|c|c|}
\hline \multirow{3}{*}{$\begin{array}{c}\text { Eat when they } \\
\text { are tension or } \\
\text { boring. }\end{array}$} & \multicolumn{4}{|c|}{ All the time } & \multicolumn{4}{|c|}{ Sometimes } & \multicolumn{4}{|c|}{ No } \\
\hline & \multicolumn{2}{|c|}{2007} & \multicolumn{2}{|c|}{2016} & \multicolumn{2}{|c|}{2007} & \multicolumn{2}{|c|}{2016} & \multicolumn{2}{|c|}{2007} & \multicolumn{2}{|c|}{2016} \\
\hline & $\mathrm{N}$ & $\%$ & $\mathrm{~N}$ & $\%$ & $\mathrm{~N}$ & $\%$ & $\mathrm{~N}$ & $\%$ & $\mathrm{~N}$ & $\%$ & $\mathrm{~N}$ & $\%$ \\
\hline Total & 19 & $9 \%$ & 43 & $24.7 \%$ & 82 & $38.9 \%$ & 60 & $34.5 \%$ & 110 & $52.1 \%$ & 71 & $40.8 \%$ \\
\hline
\end{tabular}

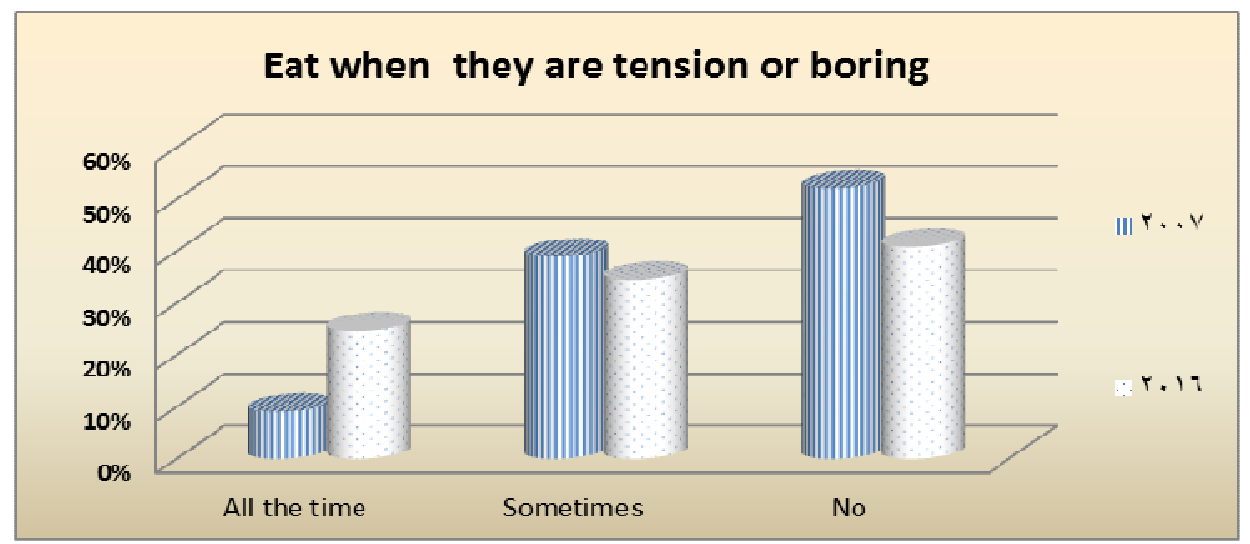

Figure (9): Distribution of students according to eating because of tension or boring in 2007 and 2016.

$$
\mathrm{t}=2.758 \quad \mathrm{P} \text { value }=0.0006
$$

The results table (10) and Figure (10) showed the comparison of female students according to king of food eats between meals in years 2007 and 2016. It is noted that the most of female student 102(48.3\%), 86 
$(49.4 \%)$ eats snacks in the years 2007and 2016 respectively, While $80(38 \%), 83(47.7 \%)$ eats fruits, vegetables, and fresh juice in the years 2007 and 2016 respectively.

Relationship between king of food eats between meals in 2007 and 2016 indicated that the difference is considered to be extremely statistically significant in Significant level $0.05(\mathrm{t}=3.199$, $\mathrm{P}$ value $=0.0015)$.

On the other hand Abdallah et al (2010) reported that the percentage of students who rarely eat vegetables and fruits were respectively $32.2 \%$ and $36.1 \%$, and those who eat them once or twice per week were $32.2 \%$ and $40.3 \%$.

Table (10): Distribution of students by their foods eats between meals in 2007 and 2016.

\begin{tabular}{|c|c|c|c|c|c|c|c|c|c|c|c|c|}
\hline \multirow{3}{*}{$\begin{array}{l}\text { Kind of food } \\
\text { eats between } \\
\text { meals. }\end{array}$} & \multicolumn{4}{|c|}{$\begin{array}{c}\text { Fruits \& vegetables } \\
\text { \&fresh juice }\end{array}$} & \multicolumn{4}{|c|}{ Snacks food } & \multicolumn{4}{|c|}{ Other } \\
\hline & \multicolumn{2}{|c|}{2007} & \multicolumn{2}{|c|}{2016} & \multicolumn{2}{|c|}{2007} & \multicolumn{2}{|c|}{2016} & \multicolumn{2}{|c|}{2007} & \multicolumn{2}{|c|}{2016} \\
\hline & $\mathrm{N}$ & $\%$ & $\mathrm{~N}$ & $\%$ & $\mathrm{~N}$ & $\%$ & $\mathrm{~N}$ & $\%$ & $\mathrm{~N}$ & $\%$ & $\mathrm{~N}$ & $\%$ \\
\hline Total & 80 & $38 \%$ & 83 & $47.7 \%$ & 102 & $48.3 \%$ & 86 & $49.4 \%$ & 29 & $13.7 \%$ & 5 & $2.9 \%$ \\
\hline
\end{tabular}

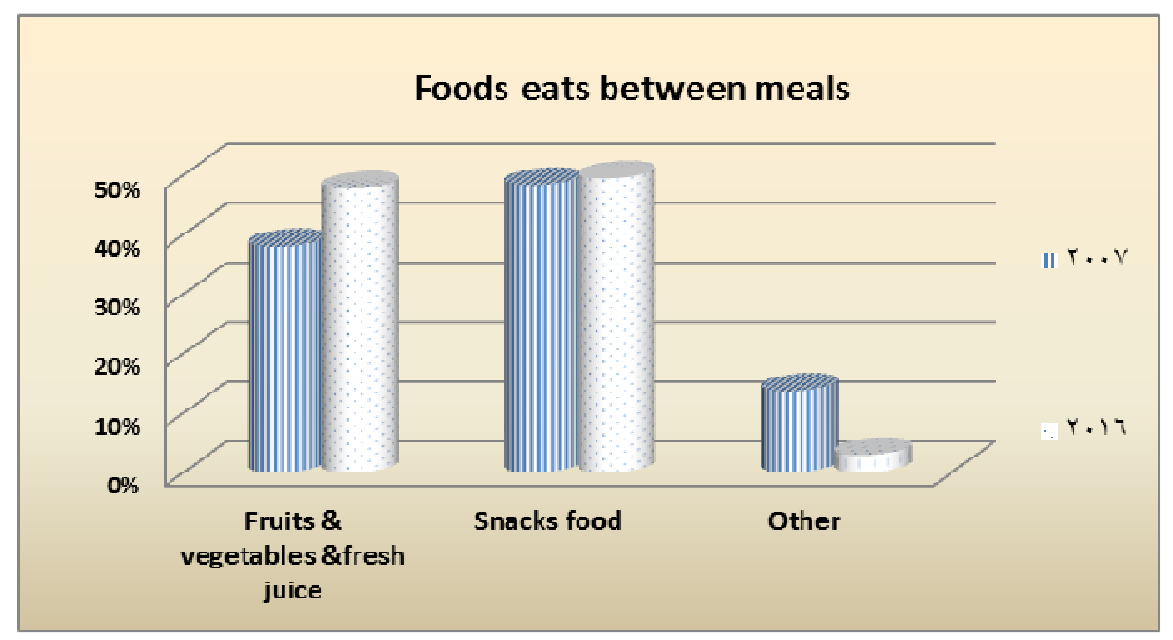

Figure (10): Distribution of students by their foods eats between meals in 2007 and 2016.
$\mathrm{t}=3.199$
$\mathrm{P}$ value $=0.0015$ 
The results in table (11) and Figure (11) showed the comparison of female students according to their preferred place for eating in years 2007 and 2016. It is noted that the most of female student $160(75.8 \%), 108$ $(62.1 \%)$ preferred Watching TV when they eating in the years 2007 and 2016 respectively, While 51(24.2\%), 66 (37.9\%) preferred eating in another place like kitchen or living room table or in bed room in the years 2007and 2016 respectively.

Relationship between preferr place to eat in 2007 and 2016 indicated that the difference is considered to be extremely statistically significant in Significant level $0.05(\mathrm{t}=3.199$, $\mathrm{P}$ value $=0.0015)$.

Table (11): Frequency and distribution of students by their preferred place to eat in 2007 and 2016.

\begin{tabular}{|c|c|c|c|c|c|c|c|c|}
\hline \multirow{3}{*}{$\begin{array}{c}\text { Preferred } \\
\text { place to eat }\end{array}$} & \multicolumn{4}{|c|}{ Watching TV } & \multicolumn{4}{|c|}{$\begin{array}{c}\text { Other place(kitchen \&living } \\
\text { room table \&bed room) }\end{array}$} \\
\hline & \multicolumn{2}{|c|}{2007} & \multicolumn{2}{|c|}{2016} & \multicolumn{2}{|c|}{2007} & \multicolumn{2}{|c|}{2016} \\
\hline & $\mathrm{N}$ & $\%$ & $\mathrm{~N}$ & $\%$ & $\mathrm{~N}$ & $\%$ & $\mathrm{~N}$ & $\%$ \\
\hline Total & 160 & $75.8 \%$ & 108 & $62.1 \%$ & 51 & $24.2 \%$ & 66 & $37.9 \%$ \\
\hline
\end{tabular}

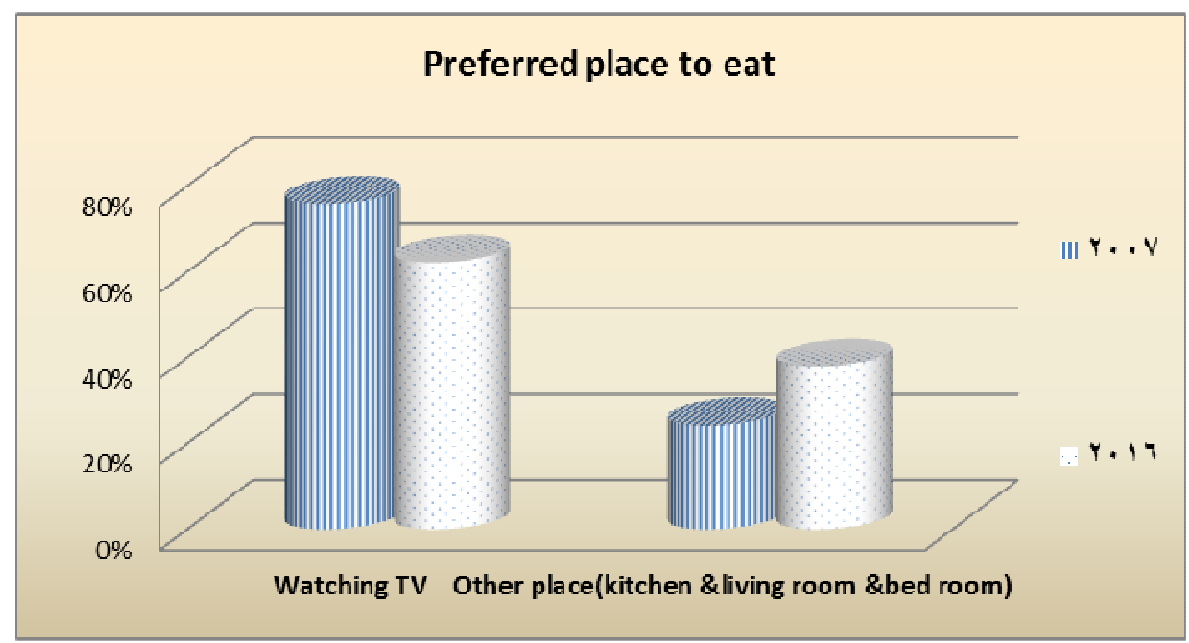

Figure (11): Frequency and distribution of students by their preferred place to eat in 2007 and 2016.

$\mathrm{t}=2.947$

$\mathrm{P}$ value $=0.0034$ 
The results in table (12) and Figure (12) showed the comparison of female students according to people they eat with in years 2007 and 2016. It is noted that the most of female student $150(71.1 \%), 110(63.2 \%)$ eating with their family in the years 2007 and 2016 respectively, While 44(20.9\%), 46 (26.4\%) eating alone in the years 2007 and 2016 respectively.

Relationship between people they eating with in 2007 and 2016 indicated that the difference is considered to be not statistically significant in Significant level $0.05(\mathrm{t}=1.512, \mathrm{P}$ value $=0.1314)$.

This finding are in agreement with Abdallah et al (2010) noted that sharing meals with family was a common habit among the students; $66.4 \%$ of them eat daily with their families.

Table (12): Frequency and distribution of student according to people they eating with in 2007 and 2016.

\begin{tabular}{|c|c|c|c|c|c|c|c|c|c|c|c|c|}
\hline \multirow{3}{*}{$\begin{array}{l}\text { People who } \\
\text { eat with you }\end{array}$} & \multicolumn{4}{|c|}{ The family } & \multicolumn{4}{|c|}{ Alone } & \multicolumn{4}{|c|}{$\begin{array}{l}\text { Other (with my } \\
\text { friends) }\end{array}$} \\
\hline & \multicolumn{2}{|c|}{2007} & \multicolumn{2}{|c|}{2016} & \multicolumn{2}{|c|}{2007} & \multicolumn{2}{|c|}{2016} & \multicolumn{2}{|c|}{2007} & \multicolumn{2}{|c|}{2016} \\
\hline & $\mathrm{N}$ & $\%$ & $\mathrm{~N}$ & $\%$ & $\mathrm{~N}$ & $\%$ & $\mathrm{~N}$ & $\%$ & $\mathrm{~N}$ & $\%$ & $\mathrm{~N}$ & $\%$ \\
\hline Total & 150 & $71.1 \%$ & 110 & $63.2 \%$ & 44 & $20.9 \%$ & 46 & $26.4 \%$ & 17 & $8.1 \%$ & 18 & $10.3 \%$ \\
\hline
\end{tabular}

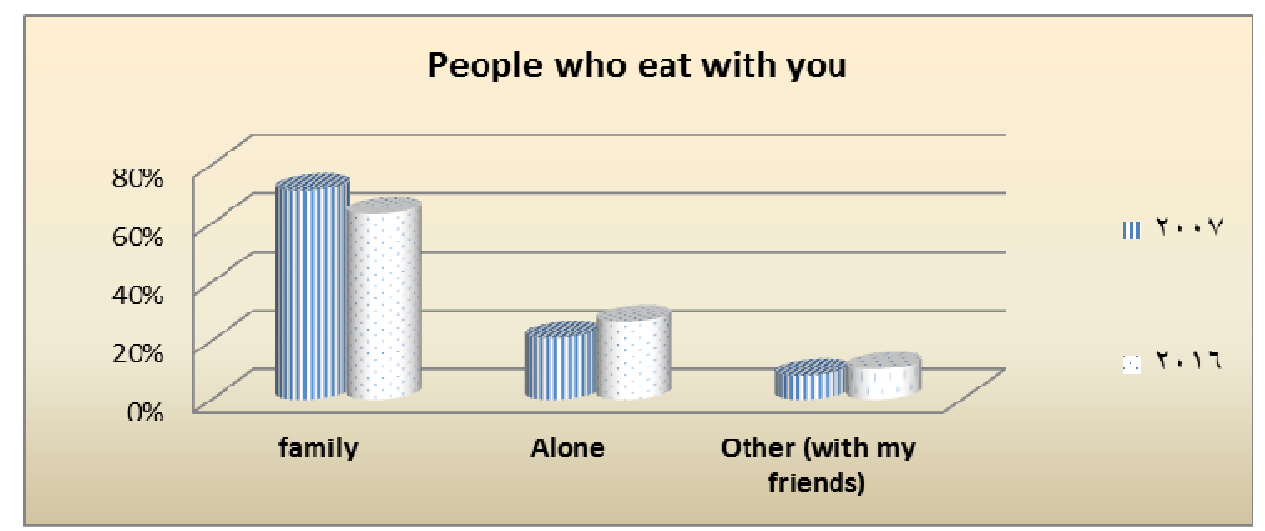

Figure (12): Frequency and distribution of student according to people they eating with in 2007 and 2016.

$$
\mathrm{t}=1.512 \quad \mathrm{P} \text { value }=0.1314
$$


The data in table (13) and Figure (13) showed the comparison of female students according to food awareness in years 2007 and 2016. It is noted that $87(41.2 \%), 58(33.3 \%)$ of female student were good food awareness in the years 2007and 2016 respectively, While 104(49.3\%), 43 (24.7\%) were medium food awareness in the years 2007and 2016 respectively, and $20(9.5 \%), 73(41.9 \%)$ were poor food awareness in the years 2007 and 2016 respectively.

Relationship between feeding awareness in 2007 and 2016 indicated that the difference is considered to be extremely statistically significant in Significant level $0.05(t=5.257$, $P$ value $=0.0001)$.

Table (13): Frequency and distribution of students by their feeding awareness in 2007 and 2016.

\begin{tabular}{|c|c|c|c|c|c|c|c|c|c|c|c|c|}
\hline \multirow{3}{*}{$\begin{array}{c}\text { Feeding } \\
\text { awareness }\end{array}$} & \multicolumn{4}{|c|}{ Good food awareness } & \multicolumn{4}{|c|}{ Medium food awareness } & \multicolumn{4}{|c|}{ Poor food awareness } \\
\hline & \multicolumn{2}{|c|}{2007} & \multicolumn{2}{|c|}{2016} & \multicolumn{2}{|c|}{2007} & \multicolumn{2}{|c|}{2016} & \multicolumn{2}{|c|}{2007} & \multicolumn{2}{|c|}{2016} \\
\hline & $\mathbf{N}$ & $\%$ & $\mathbf{N}$ & $\%$ & $\mathbf{N}$ & $\%$ & $\mathbf{N}$ & $\%$ & $\mathbf{N}$ & $\%$ & $\mathbf{N}$ & $\%$ \\
\hline Total & 87 & $41.2 \%$ & 58 & $33.3 \%$ & 104 & $49.3 \%$ & 43 & $24.7 \%$ & 20 & $9.5 \%$ & 73 & $41.9 \%$ \\
\hline
\end{tabular}

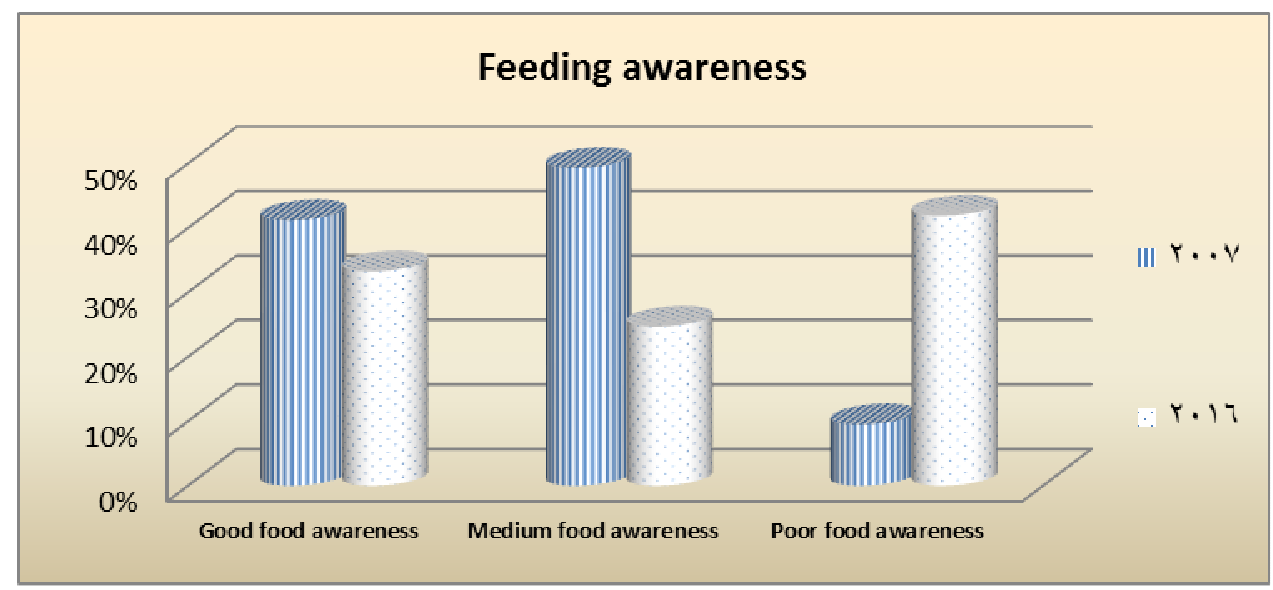

Figure (13): Frequency and distribution of students by their feeding awareness in 2007 and 2016.

$$
\mathrm{t}=5.257 \quad \mathrm{P} \text { value }=0.0001
$$


- Food Habits and Food Awareness Among University Female Students: Comparative Study

\section{Conclusion}

In conclusion, the results showed that female university students in 2007 have food awareness more than in 2016. However, most female students prefer eating when they watching TV. Recommendation

1. Other studies are needed for all age groups to study food awareness and food habits.

2. Media should Highlights for food habits.

\section{REFERENCES}

- Abd El-Salam, H, A. (1998): Obesity trends among university female students, M.Sc. thesis, Faculty of Home Economic, Helwan University, Cairo, Egypt.

- Abdallah S Al-Rethai, Alaa-Eldin A Fahmy $\dagger$ and Naseem M Al-Shwaiyat (2010): Obesity and eating habits among college students in Saudi Arabia: a cross sectional study, Nutrition Journal, 10.1186/1475-2891-9-39.

- Abdel-Hady El-Gilany, MD and Ragaa El-Masry, MD (2011): Overweight and Obesity among Adolescent School Students in Mansoura, Egypt, Childhood Obesity, 7(3): 215-222.10.1089/chi.2011.0008.

- Aucott L, Poobalan A, McCallum M, Smith WCS (2014): Mental well-being related to lifestyle and risky behaviours in 18-25 year old: evidence from NorthEast Scotland, Int J Public Health Res; 4:431-440.

- Berkey CS, Rockett HR, Gillman MW, Field AE, and Colditz GA (2003): Longitudinal study of skipping breakfast and weight change in adolescents. Int J Obes Relat Metab Disord , 27:1258-1266.

- Croezen S, Visscher TL, Ter Bogt NC, Veling ML, and Haveman-Nies A(2009): Skipping breakfast, alcohol consumption and physical inactivity as risk factors for overweight and obesity in adolescents: results of the E-MOVO project.Eur J Clin Nutr , 63:405-412.

- Ganasegeran K, Al-Dubai SA, Qureshi AM, Al-Abed AA, Rizal AM, Aljunid SM (2012): Social and psychological factors affecting eating habits among university students in a Malaysian medical school: a cross-sectional study, Nutr J; 11:48. 
- Heba A. Abdel Sadek, Mervat W. Abu-Nazel, Zeinab N. Shata and Nesrin K. Abd El-Fatah (2016): The relationship between the BMI and the emotional status of Alexandria University students, Egypt, Journal of the Egyptian Public Health, Association, 91:101-108

- Keller A., Bucher Della Torre S. (2015): Sugar-Sweetened Beverages and Obesity among Children and Adolescents: A Review of Systematic Literature Reviews. Child. Obes. ;11:338-346.

- Kolodinsky J, Harvey-Berino JR, Berlin L, Johnson RK, Reynolds TW (2007): Knowledge of Current Dietary Guidelines and Food Choice by College Students: Better Eaters Have Higher Knowledge of Dietary Guidance. J Am Diet Assoc. 2007, 107: 1409-1413. 10.1016/j.jada. 05.016.

- Mehliba, W, H. (1999): A Follow- up Program to Study Effect of Dietary Management and Behaviour Modification on Control on Obesity in Adult Females, Ph.D. thesis, Cairo university, Egypt.

- Mota J, Fidalgo F, Silva R, Ribeiro JC, Santos R, Carvalho J, and Santos MP(2008): Relationships between physical activity, obesity and meal frequency in adolescents.Ann Hum Biol , 35:1-10.

- Najat Yahia, Alice Achkar, Abbass Abdallah and Sandra Rizk (2008): Eating habits and obesity among Lebanese university students, Nutrition Journal DOI: 10.1186/1475-2891-7-32.

- Vermeulen. E, K Stronks, M Visser, I A Brouwer, M B Snijder, R J T Mocking, E M Derks, A H Schene and M Nicolaou(2017): Dietary pattern derived by reduced rank regression and depressive symptoms in a multi-ethnic population: the HELIUS study, European Journal of Clinical Nutrition advance , 10.1038/ejen.2017.61. 


\section{العادات الغذائية والوكي الذذائي لطالبات البامهة : دراسة هقارنة علاطلعت سحلول}

\section{الملخص العربي}

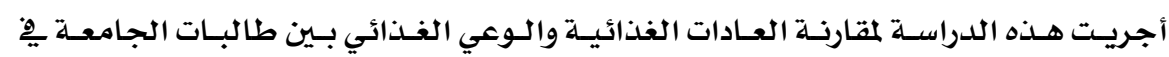

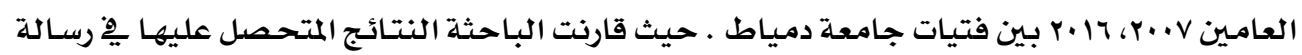

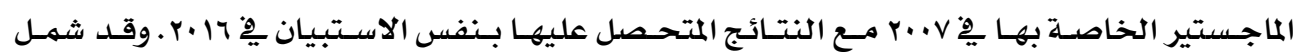
الاسـتبيان التعـرف علـى مسستوى التعلـيهم والمستوى الـوظيفي واسـتبيان آخـر للتعـرف علـى العـادات

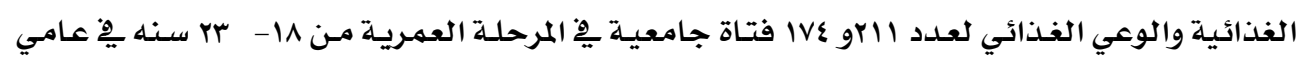

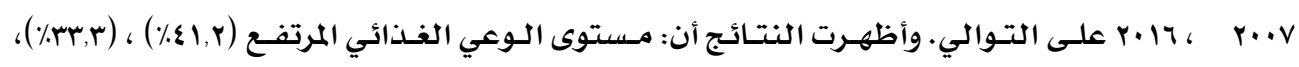

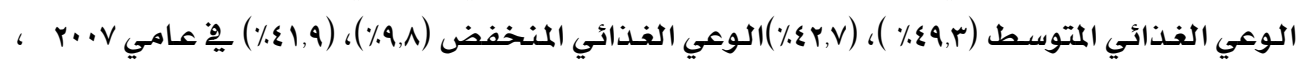

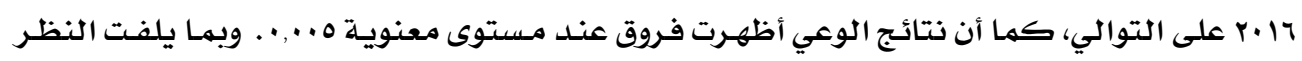

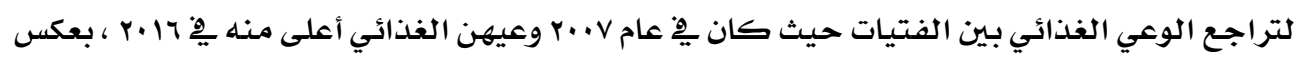

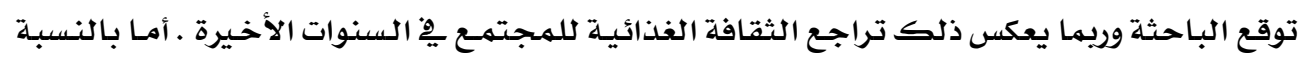

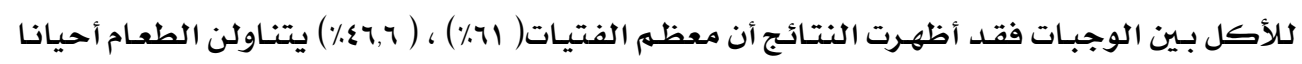

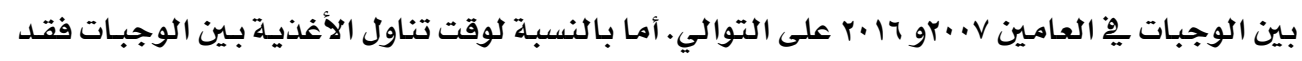

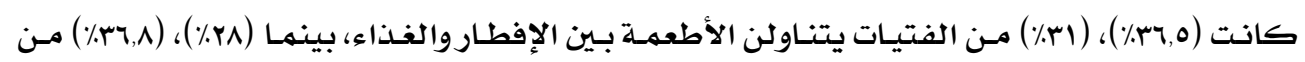

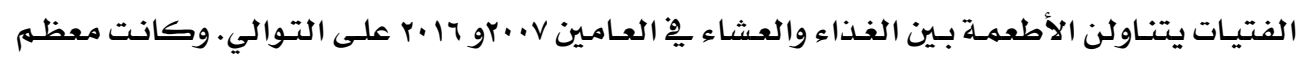

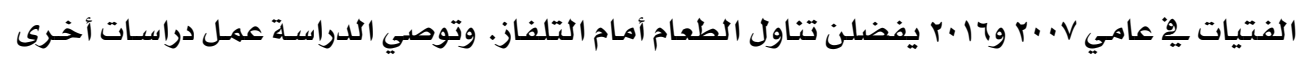

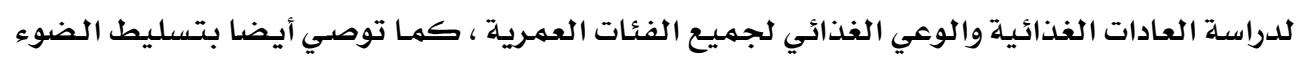
على العادات الغذائية مـن قبل الإعلام.

قسم الاقتصاد المنزلي- كلية التربية النوعية - جامعة دمياط- دمياط- مصر 